\title{
A análise da cadeia produtiva dos catados como subsídio à gestão costeira: as ameaças ao trabalho das mulheres nos manguezais e estuários no Brasil *
}

\author{
The analysis on the extractiv shellfish productive chain as subside to coastal \\ management: the threats to the women's work in Brazilian mangroves and estuaries
}

\author{
Tatiana Walter ${ }^{\circledR, 1}$, J. Wilkinson $^{2}$, P. de A.Silva ${ }^{2}$
}

\section{RESUMO}

O presente artigo apresenta a aplicação do aporte analítico dos sistemas agroalimentares associado à Sociologia Econômica na análise de questôes afeitas à pesca artesanal, tendo como perspectiva uma abordagem sistêmica e territorializada, centrais à gestão costeira. Para tal, analisou a cadeia produtiva dos catados oriundos da mariscagem em oito municípios litorâneos da Bahia por meio de um aporte teórico-analítico diversificado que permitiu a compreensão dos diversos fenômenos que afetam a atividade das mulheres na produção de catados, incluindo aqueles oriundos da dinâmica territorial. A coleta de dados concatenou a análise de informaçóes pretéritas com pesquisa-observante e realizaçáo de entrevistas semiestruturadas, no período de julho de 2009 a junho de 2010, envolvendo informaçóes sobre 94 comunidades pesqueiras. Os resultados denotam a complexidade em torno das estratégias de comercialização, ainda que os fluxos de produção estejam predominantemente circunscritos à região. Verificou-se que, considerando as demais atribuiçóes das mulheres, tanto na elaboração de outros produtos pesqueiros como frente aos afazeres domésticos, tem-se na degradação dos manguezais um processo que concatena sobrecarga de trabalho com perda de produção e renda. Degradação esta oriunda da expansão urbana, do turismo e da poluição relacionada à maricultura e à atividade petrolífera. Dois outros fatores são importantes entraves nesta cadeia produtiva: as exigências sanitárias que discriminam as práticas domésticas em torno do beneficiamento dos catados e a falta de saúde laboral associada à ausência de mecanismos de seguridade social. Em relação aos resultados obtidos, este conjunto de fatores representa uma ameaça às marisqueiras, no que tange à manutenção de sua reproduçáo social. Conclui-se, ainda, que o aporte teórico-analítico adotado é adequado à análise das questôes afetas à atividade pesqueira, especialmente por contemplar uma abordagem capaz de inseri-la como parte da gestáo costeira.

Palavras-chaves: Pesca Artesanal, Mariscagem, Sistemas Agroalimentares, Sociologia Econômica, Bahia.

@ - Corresponding author: tatianawalter.labgerco@gmail.com

1 - Universidade Federal do Rio Grande/FURG, Laboratório de Gerenciamento Costeiro - LabGERCO - Instituto de Oceanografia - Caixa Postal 474, Rio Grande/RS, CEP: 96.203-900.

2 - Universidade Federal Rural do Rio de Janeiro, Centro de Pós-Graduação em Ciências Sociais em Desenvolvimento, Agricultura e Sociedade, CPDA/UFRRJ. Av. Presidente Vargas 417, $8^{\circ}$ andar, Centro, Rio de Janeiro, RJ, CEP: 20071-003. 


\section{ABSTRACT}

This research presents an application of the analytical frame of Localized Agrifood Systems associated to the Economic Sociology on the analysis of questions related to artisanal fishery, having as perspective a systemic and territorialized approach, which is central to coastal management. Thus, the extractivist shellfish production chain was analyzed on eight municipalities on the coast of Bahia in a varied theoretical and analytical way which allows the comprehension of different phenomenon that affect the work of women in this production, including those from the territorial dynamic. The analyzed information was collected on the basis of direct interviews and observational research carried out between July, 2009 and June, 2010, together with secondary sources from ninety four fishing communities. The results show the complexity around the commercial strategies, though most of the production fluxes are circumscribed in the region. We verified, considering the others attributions of the women, as far on elaboration of fishing products as the domestic work, the mangroves degradation is the process that relates overwork with losses on the production and income. This degradation derives from urban expansion and the pollution associated to mariculture and oil activities. Two other factors are also important in this production chain: the recommended sanitary conditions, which discriminate the domestic practices on the processing of the shellfish and the lack of labour healthy associated to absence of social security. In relation to the achieved results, this group of factors represents a threat to the women regarding their social reproduction. We concluded, also that the theoretical and analytical contributions here adopted are suitable to analyze the artisanal fishery activity, especially because include an approach able to insert it on the coastal management.

Keywords: Artisanal Fishery, Shellfish collection, Localized Agrifood Systems, Economic Sociology, Bahia.

\section{INTRODUÇÃO}

A gestão costeira e/ou gerenciamento costeiro reporta às açóes de gestão ambiental na zona costeira, tendo como perspectiva uma abordagem sistêmica e territorial. Sistêmica, no que concerne à análise sobre os problemas ambientais e a proposição de açôes de intervenção, considerando as dimensôes político-institucionais, sociais, econômicas e ambientais da gestáo. Territorial, por considerar um espaço delimitado - a zona costeira - em sua interaçáo com o ambiente marinho e terrestre. Na gestão costeira, os processos de uso e ocupação do espaço são considerados relevantes, o que denota a importância de aportes analíticos que fazem uso de uma abordagem territorial.

$\mathrm{Na}$ perspectiva da gestão costeira é possível inferir que a gestão do uso dos recursos pesqueiros necessita incorporar tais componentes: sistêmico e territorial, dado que sua ênfase é a análise sobre o esforço de pesca e sobre o regime de propriedade dos recursos pesqueiros. Algumas reflexóes em torno das limitaçôes sobre a gestão pesqueira encontram-se em Walter et al., (2012) elucidadas por meio da realidade das comunidades pesqueiras artesanais no estado de Pernambuco. Para as autoras, o processo de ocupaçáo e degradação da zona costeira é o principal responsável pelas condiçốes de precariedade socioambiental em que vivem as comunidades de pescadores da regiáo metropolitana de Recife. Como conclusão de sua análise ressaltam: “(...) este diagnóstico explicita que a diminuição da produção pesqueira necessita ser avaliada à luz do conjunto de atividades que ocupam o território e os regramentos devem ser estabelecido neste conjunto, ou seja, por meio de um enfoque que considere os recursos pesqueiros como parte do ambiente (Walter et al, 2012: 13).

Nesta perspectiva, o presente artigo apresenta o aporte analítico dos sistemas agroalimentares associado à Sociologia Econômica como uma possibilidade de análise da atividade pesqueira, em uma perspectiva sistêmica e territorializada, gerando subsídios ao debate em torno da gestão costeira e da inserção das questóes afeitas aos pescadores artesanais neste processo.
De forma específica, o artigo discorre sobre a aplicação deste aporte na cadeia produtiva dos catados oriundos da pesca artesanal em uma porção do litoral da Bahia, buscando identificar os fatores que influenciam sua dinâmica, destacando a participação das mulheres.

$\mathrm{Na}$ área estudada são capturadas mais de sessenta espécies nos estuários, manguezais e no ambiente marítimo para manutenção da pesca artesanal. $\mathrm{O}$ trabalho, que vai desde a captura da espécie até o tratamento realizado para seu beneficiamento e sua conservação, envolve toda a família e resulta em quatro produtos principais: pescados, catados, mariscos vivos e peixes secos. Cada um dos produtos e alguns de seus subprodutos abastece mercados distintos e estabelece uma complexa cadeia de relaçôes sociais (Walter, 2010).

Os catados são produtos oriundos da captura de mariscos, ou seja, de moluscos, bivalves e crustáceos (ostras, lambretas, sururu, caranguejos, siri e aratus) e do seu tratamento, que envolve o cozimento, extração da casca e processamento ("cata").

A motivação em estudar a cadeia produtiva dos catados na região deve-se: i) as espécies que o compóem serem extraídas de manguezais e estuários, ambiente relevantes na zona costeira; ii) do produto ser resultado do trabalho das mulheres ${ }^{1}$, que atuam de forma singular nas etapas de extração e beneficiamento desta cadeia, atividade esta localmente denominada de mariscagem.

Nesta perspectiva, tem-se na análise da cadeia produtiva dos catados a possibilidade de compreender os fatores que influenciam a dinâmica dos atores sociais presentes nos diversos elos, em especial, quais fatores são explicativos das relações entre produção e ambiente.

Esclarecemos que a produção de uma gama variada de produtos pelas famílias pesqueiras é considerada uma característica intrínseca da pesca artesanal na região, necessária à manutençáo da biodiversidade e da renda familiar ao longo do ano (Walter \& Wilkinson, 2011).

1 - Apesar do predomínio de mulheres na atividade de mariscagem, há também homens que atuam na etapa de captura tais espécies. 
Assim, ao delimitarmos a cadeia produtiva dos catados como objeto deste artigo, desejamos demarcar uma relação ambiente sociedade, que faz uso de um ecossistema específico (o manguezal) e naqueles produtos cujo trabalho resulta, principalmente da força de trabalho das mulheres. Contudo, é importante compreendermos que a produção de catados é parte das estratégias das unidades produtivas familiares para sua reprodução enquanto "famílias de pescadores", o que envolve os demais integrantes das famílias e a elaboração de outros produtos pesqueiros.

\subsection{O aporte teórico-analítico dos sistemas agroalimentares e sua adequaçáo à pesquisa}

Para realização da pesquisa utilizamos um aporte teórico-analítico diversificado, associando-o ao de sistemas agroalimentares à Sociologia Econômica como uma espécie de "bricolagem", conforme detalhado em Walter (2010). Estes, comumente utilizados na compreensão de cadeias produtivas informais e na contribuição da agricultura familiar na produçáo de alimentos, têm sido pouco explorados à análise da produção de pescado, em especial para compreensão do papel dos pescadores artesanais e as características da cadeia produtiva dos alimentos por eles extraídos. Alguns exemplos na literatura são: Ponte (2008) que analisa a influência da certificaçáo ambiental na cadeia produtiva da pesca industrial da merluza na África do Sul; Phyne \& Mansilla (2003) analisa a cadeia produtiva do salmão no Chile, evidenciando maior precariedade nas condiçôes de trabalho das mulheres; Santos (2005) analisa a cadeia produtiva do pescado oriundo da pesca artesanal no Nordeste Paraense e; Lins (2006) que analisa a maricultura em Santa Catarina por meio do aporte de Sistemas Agroalimentares Localizados.

A abordagem de cadeia produtiva (Gereffi, 1999; Gereffi et al., 2005; Batalha \& Silva, 2007; Zilberstajn, 2000) auxiliou na concepção de uma análise sistêmica e mesoanalítica, necessária à compreensão dos fenômenos que explicam a cadeia produtiva na escala territorial adotada, tanto quanto, de compreender os diversos fatores que interferem na cadeia produtiva dos catados enquanto atividade produtiva das mulheres.

Considerando a dinâmica territorial da atividade pesqueira, em que a cadeia produtiva está circunscrita na área de estudo, adotamos a concepção de Sistema Agroalimentar Localizado - SIAL ou SAL, proposta por Muchnik (2006).

O conceito de Unidade Doméstica de Produção da Economia Popular, adaptado de Coraggio (2000) auxiliounos na análise dos primeiros elos da cadeia produtiva, envolvendo a etapa extrativa, a de beneficiamento e a primeira comercialização permitindo identificar mais de uma tipologia de intermediário. Assim, a atividade produtiva foi organizada a partir da função desempenhada pelos membros da família e as atividades de extração, beneficiamento, produção de insumos foi compreendida por meio desta organizaçấo e de sua relação com o primeiro-intermediário. Ou seja, a Unidade Doméstica de Produção Familiar (UDP) caracteriza-se pela participação da família, composta por homens e mulheres nas atividades de captura e de beneficiamento.

A preocupação em torno de padrôes de qualidade, enfoque da Teoria das Convençóes (Boltanski \& Thévenot,
1991), contribuiu na análise sobre sua construção social, ou seja, são os atores envolvidos ao longo da cadeia produtiva que estabelecem o significado de qualidade, sendo a mesma um conceito socialmente construído. O enfoque de redes sociais da Sociologia Econômica (Granovetter, 1973; 1974; 1985; 1992) contribuiu para compreendermos as relaçóes sociais presentes na cadeia produtiva.

\section{MATERIAL E MÉTODOS}

\section{1. Área de Estudo}

Para análise da cadeia produtiva dos catados, delimitamos como área de estudo os oito municípios litorâneos que integram à Sub-região do Baixo Sul da Bahia: Valença, Cairu, Taperoá, Ituberá, Nilo Peçanha, Igrapiúna, Camamu e Maraú (Figura 1).

Segundo Fischer (2007), o Baixo Sul da Regiáo Sul da Bahia é uma das quinze regióes econômicas do Governo do Estado da Bahia e engloba uma área com onze municípios. Além dos que integram a área de estudo, tem-se em sua porçáo interior: Piraí do Norte, Presidente Tancredo Neves e Teolândia. Para Companhia de Desenvolvimento e Ação Regional - CAR, a organização deste conjunto de onze municípios enquanto uma sub-região deve-se a importância da agricultura familiar, cuja produção volta-se principalmente a cultivos perenes de cravo-da-índia, cacau, guaraná, seringueira, pimenta-do-reino, coco-da-baía, dendê, banana, laranja e café, que em conjunto, representavam $87,3 \%$ do total de área colhida, em 1993 (CAR, 1997) ${ }^{2}$.

Em sua porção litorânea, a pesca artesanal é o principal meio de vida de aproximadamente treze mil pescadores e marisqueiras (MPA, 2010), distribuídos em noventa e quatro comunidades e bairros, segundo informaçóes do Registro Geral da Pesca, disponibilizadas pelo Ministério da Pesca e Aquicultura por meio da Lei de Acesso à Informação, Lei no $12.527 / 2011$. Em 2005, a produçáo total de frutos do mar foi em torno de 15 mil toneladas, sendo responsável por um montante de $\mathrm{R} \$ 78$ milhóes apenas na primeira comercialização, significando $32,5 \%$ da produção em peso e $35 \%$ da produção em valor do litoral baiano (Fundação Prozee et al., 2006).

Para organizaçáo da pesquisa, nosso conhecimento prévio sobre o litoral do Baixo Sul sugeria que o fluxo de produção se distribuía espacialmente em três áreas, sendo que em cada uma delas parte das comunidades se articula em torno de um polo pesqueiro, ou seja, com aqueles municípios melhor estruturados em termos de oferta de serviços: Camamu, Taperoá/Ituberá e Valença. Este arranjo pode ser definido

2 - A identidade territorial da região resultou em sua inserção, em 2003, na Política de Desenvolvimento Rural do Ministério do Desenvolvimento Agrário - MDA e em Território da Cidadania pelo Governo Federal, em 2009. A importância da pesca artesanal e a necessidade de maior inserção dos pescadores nos Territórios da Cidadania, fez com que em meados de 2009 o Ministério de Pesca e Aquicultura definisse o Baixo Sul como um de seus Territórios de Aquicultura e Pesca (MDA, 2010). Tais políticas tem como proposição o planejamento do desenvolvimento a partir da territorialização das regióes cujas características culturais, sociais, econômicas, agrícolas, dentre outras, constituam uma identidade, um sentimento de pertencimento (MDA, Op. cit.) 
como três cadeias produtivas organizadas espacialmente, cada uma delas articulando a produção das comunidades pesqueiras (direta ou indiretamente) com a sede de um desses quatro municípios e abastecendo as localidades turísticas que também se vinculam a ela, dado a oferta de serviços. Cada um dos conjuntos, envolvendo comunidades pesqueiras e turísticas e o respectivo polo pesqueiro, foi definido como um microssistema alimentar localizado - microSAL.

Remetemos aqui à noçáo de SAL proposta por Muchnik (2006), dado que o SAL busca compreender o funcionamento da cadeia produtiva a partir do enfoque sobre o território. Tal proposição visa captar aspectos relacionados à dinâmica da cadeia produtiva de forma mais aprofundada, cuja organização em um único sistema não permitiria.

É preciso, no entanto, relacionarmos também alguns limites dessa abordagem. O primeiro deve-se ao fato de algumas comunidades pesqueiras se relacionarem com mais de um sistema. E o segundo relaciona-se a alguns dos aspectos a serem analisados, em especial, o ambiente institucional, que extrapolam o nível microrregional.

Ademais, no que concerne às características da atividade pesqueira, ou seja, da etapa produtiva, os três microssistemas são bastante similares. Em consequência, têm-se a organização das informaçôes considerando a existência de três microSAL que se articulam em um sistema maior, também localizado, constituído pelo Território Baixo Sul como um todo, ou seja, incluindo a área rural e os municípios do interior, apesar da etapa extrativa ocorrer nas comunidades litorâneas.

Por último, destacamos que a pesquisa foi estruturada de forma a analisar a totalidade das comunidades e bairros pesqueiros de oito dos municípios constituintes litorâneos do Baixo Sul.

\subsection{Procedimentos de Pesquisa}

A coleta de dados ocorreu no período de julho de 2009 a junho de 2010 por meio de pesquisa qualitativa envolvendo: análise de dados secundários; observação participante; e realização de entrevistas junto a atores da cadeia produtiva. Por meio desses três métodos foram obtidas informaçóes que caracterizassem todas as etapas da cadeia produtiva e os fatores que a influenciam (ambiente institucional). Conforme exposto por Haguette (1999), o ponto chave no controle da qualidade de dados situou-se no uso sistemático de informações de diversas fontes relacionadas ao fato observado, a fim de que se possa analisar sua consistência e sua qualidade (triangulação) na pesquisa realizada.

As informaçóes coletadas nos acervos do Instituto Brasileiro do Meio Ambiente e dos Recursos Naturais Renováveis - IBAMA e do Ministério da Pesca e Aquicultura - MPA foram coletadas com base em um roteiro específico (Apêndice 1) e organizadas em um banco de dados em planilha Excel, tendo por base a identificação e compreensão dos elos da cadeia. Os dados secundários ofereceram informaçóes a respeito de 53 comunidades pesqueiras de um universo de 94 comunidades (56,4\%). Por microssistemas a representatividade de comunidades variou entre $53,8 \%$ e 63,2\%.

No que diz respeito à técnica de observação participante, Haguette (1999) destaca o observador como parte do contexto social ao qual participa e ao mesmo tempo coleta dados. A pesquisa observante ocorreu durante o acompanhamento das atividades do "Centro Integrado da Pesca Artesanal (CIPAR) no Litoral do Baixo Sul da Bahia como instrumento de desenvolvimento local e territorial - Projeto CIPAR Baixo Sul", que teve como objetivo o planejamento da cadeia produtiva da pesca artesanal na região, por meio de um convênio entre o MPA e o Instituto de Planejamento de Gestão Governamental - IPLAN. Foram acompanhados dez eventos entre julho de 2009 e maio de 2010 compostos por oficinas, seminários e reuniōes. Além da participação nos mesmos, os resultados gerados nos eventos compuseram relatórios que subsidiaram as análises, além do registro em diário de campo.

Os eventos foram construídos sobre dois eixos temáticos principais: a perspectiva de estruturação da cadeia produtiva dos frutos do mar em cada microSAL e a organização social dos pescadores do Baixo Sul como um todo (Walter \& Wilkinson, 2011). Participaram dos eventos pescadores, marisqueiras e lideranças, em um total de cem integrantes de trinta e sete comunidades e bairros distintos.

$\mathrm{O}$ último método de pesquisa utilizado diz respeito a investigaçóes em campo por meio de entrevistas semiestruturadas junto a restaurantes, peixarias e atravessadores, comerciantes presentes em mercados públicos (Apêndice 2) e entrevistas abertas junto a gestores públicos que atuam em políticas destinadas ao setor.

As entrevistas foram precedidas do esforço em se definir o total de estabelecimentos associados a cada elo (população) para então se definir o universo total da amostra. Foram obtidas amostras superiores a $50 \%$ do total de cada tipo de estabelecimento, levando em consideração diferenças em relação ao porte, condições sanitárias e localização. As entrevistas ocorreram durante três visitas ao Baixo Sul (outubro/2009, novembro/2009 e janeiro/2010), uma a Salvador (março/2010) e uma a Brasília (junho/2010). Com exceção desta última, que teve por objetivo entrevistar gestores do MPA, as demais entrevistas foram realizadas sempre por dois pesquisadores.

Os aspectos sanitários da cadeia produtiva foram registrados por meio de observação direta e categorizados em: ruim, razoável e adequado. Para tal, os entrevistadores deveriam observar: a presença de revestimento nas paredes e chão, as condiçóes dos frutos do mar nos freezers e câmaras frias, ou seja, se soltos ou embalados, se os frutos do mar expostos estavam conservados em gelo e se havia presença de odor desagradável. A conjunção destas qualidades resultava em um dos três critérios.

No que tange ao conceito de qualidade presente na cadeia (frescor do alimento, condiçôes sanitárias, tamanho dos exemplares), ao discorrer sobre as estratégias de aquisição dos produtos, os entrevistados apresentavam os elementos que resultam em sua compreensão sobre "qualidade", o que permitiu as análises.

Por último, é importante destacar que os resultados preliminares necessários à compreensão da cadeia produtiva foram analisados em conjunto com marisqueiras e pescadores nas atividades do Projeto CIPAR Baixo Sul. As contribuições do grupo possibilitou a adequaçáo das análises, novos levantamentos e a validação dos resultados contribuindo substancialmente com essa pesquisa. 


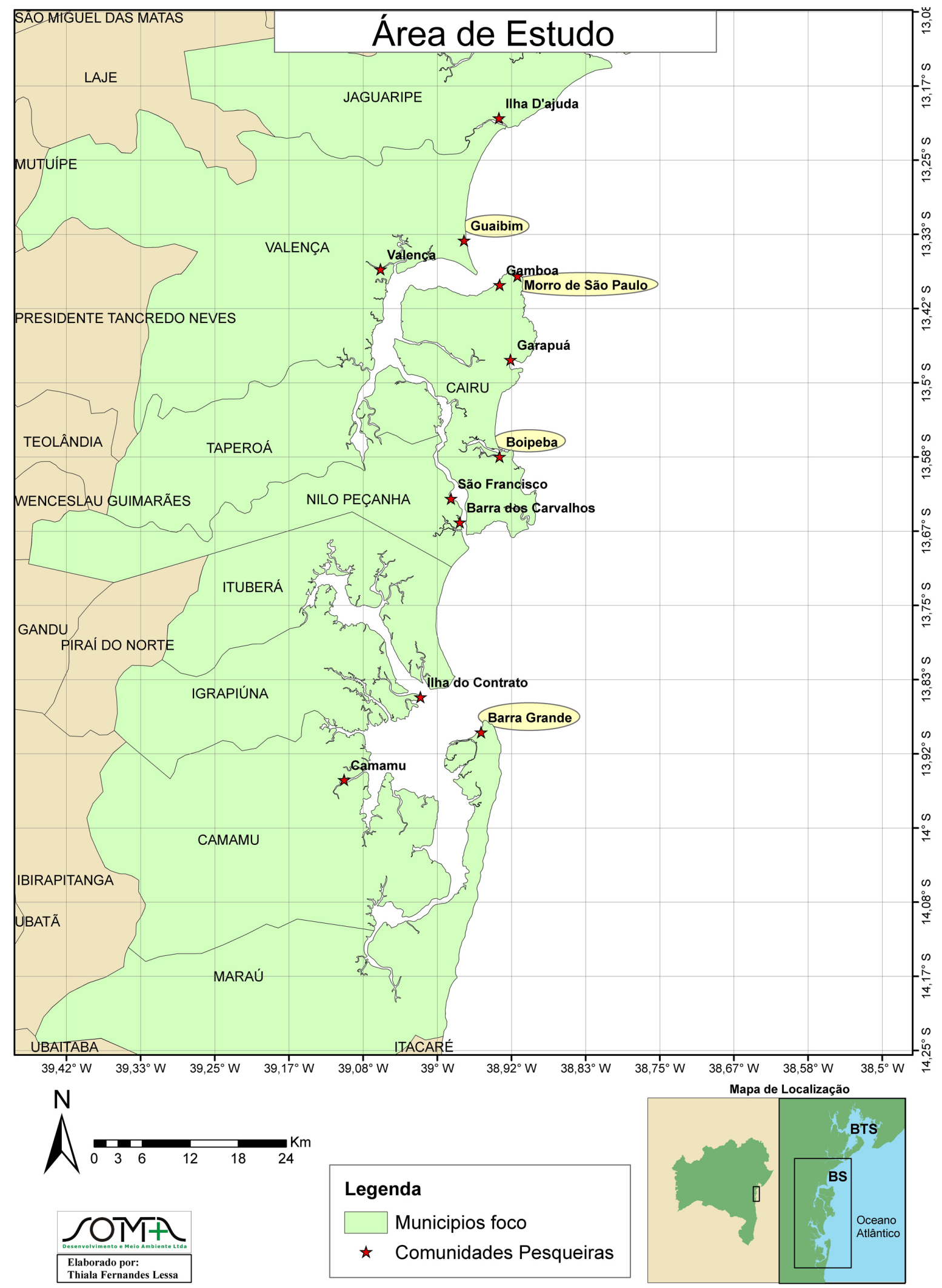

Figura 1. Área de Estudo. Foram destacadas algumas das principais comunidades pesqueiras. As localidades de Barra Grande, Boipeba e Morro de São Paulo e Guaibim possuem expressão turística.

Figure 1. Study area. The main fishery communities are highlighted. On Barra Grande, Boipeba, Morro do São Paulo and Guaibim the turism is significative. 


\subsection{Organizaçáo dos Resultados: a sobreposiçáo de elos nas cadeias produtivas e a elaboração de esquemas de fluxo dos produtos}

Para organização dos resultados optou-se pela elaboração de esquemas de fluxo, delineados para cada microssistema em dois períodos do ano: verão e inverno. Associados aos demais resultados foi possível compreender a dinâmica da cadeia produtiva dos catados e os fatores que a influenciam.

Contudo, a sobreposiçáo de elos e a diversidade de estratégias e fluxos nos demandaram alguns artifícios na organização dos resultados, como será brevemente descrito. $\mathrm{O}$ primeiro deles é consequência de um único comerciante ocupar mais de uma posição na cadeia produtiva, dada à diversidade de formas de aquisição dos catados e de destinação dos mesmos. Os intermediários-residentes em localidades turísticas, por exemplo, além de se relacionarem com as famílias de pescadores recebem a produção de outros intermediários. Nestes casos, tornam-se o segundo intermediário e ocupam posiçóes medianas na cadeia produtiva.

Intermediários-residentes em comunidades pesqueiras podem comercializar seus produtos nas feiras e mercados públicos ou mesmo de forma ambulante. Intermediáriosvisitantes também exercem tal função. Por isso, há feirantes que ocupam a posiçấo de $1^{\circ}$ intermediário e outros de segundo. Há ainda aqueles que adquirem os produtos da sua comunidade (intermediário-residente) e visitam as localidades adjacentes, caracterizando a tipologia definida como intermediário-visitante.

Já as peixarias que possuem estrutura na sede dos municípios e recebem a produção das famílias de pescadores das comunidades pesqueiras, exercem muitas vezes a funçáo de intermediário-residente junto às unidades produtivas. Também adquirem produtos de outros intermediáriosresidentes.

Assim, para compreensão desta dinâmica, os esquemas elaborados para apresentação dos resultados consideram: a) Intermediários-residentes: aqueles comerciantes que estão localizados nas comunidades pesqueiras e nas localidades turísticas, estabelecendo uma relação mais duradoura com as unidades produtivas; b) Intermediários-visitantes: não vinculados a nenhuma localidade, sua participação estará explicitada junto aos fluxos de produção; c) Peixarias: estabelecimentos situados nas sedes do município, sendo atribuído a estes o papel de peixaria e inserida a relação do comerciante com as unidades produtivas situadas nas sedes, ou seja, aquela caracterizada como intermediário-residente; d) Feiras e Mercados: comerciantes que vendem seus produtos nos mercados e feiras, independente de concomitantemente possuírem atribuição de intermediário-residente, visitante ou de unidade produtiva (pescador).

Quanto às variaçóes ao longo do ano, foram demarcados dois períodos: o inverno caracterizado pelo período entre início de março e final de setembro e; o verão, entre outubro e final de fevereiro. Tal organização visa compreender a influência do turismo de veraneio nas cadeias produtivas, dada à importância da atividade no local.

A inserção dos catados em um dado microssistema agroalimentar localizado pode variar. Assim, as análises empreendidas se apoiam em esquemas organizados a partir dos resultados obtidos ao longo da pesquisa, considerando três fluxos em termos de importância (principal, de acordo com a frequência em que foi citado; secundário ou de importância média e menos relevante, ou seja, esporádico) conforme expresso na Figura 2. Esta importância diz respeito ao interior do microSAL em questáo.

A figura 2 apresenta, também, os ícones utilizados para cada um dos elos da cadeia produtiva. Dada, ainda, a proposição em analisar sua inserção no território, a legenda organiza os fluxos a partir de três unidades territoriais principais: comunidade pesqueira, localidade turística e sede do município. Cadeias que se relacionam com outras unidades territoriais, a exemplo do interior do Baixo Sul e de Salvador terão ícones acrescidos e devidamente identificados.

Por fim, os aspectos institucionais - expressos pelos diversos atores situados na cadeia produtiva - foram apresentados em um item específico.

\section{RESULTADOS E DISCUSSÁO}

\subsection{A cadeia produtiva dos catados}

Mariscos são coletados nos manguezais e estuários com armadilhas ou manualmente, no máximo, com auxílio de utensílios domésticos, ou seja, há necessidade de poucos insumos para etapa extrativa. Por vezes, utilizam-se canoas para acessar o pesqueiro, mas é comum as mulheres irem aos manguezais e estuários a pé.

O beneficiamento consiste em cozer o animal e depois extrair a carne da casca, produzindo o catado. Em geral, esta etapa é realizada no interior da residência em consonância aos demais afazeres domésticos. Catados podem ser conservados frescos ou congelados, sendo processados e embalados na própria unidade doméstica. Comumente, são comercializados em sacos plásticos, sendo fracionados em porções de um quilo.

Extração e beneficiamento são realizados principalmente por mulheres, sendo a participação dos homens importante na colheita de lenha, necessária à etapa de cozimento do produto. $\mathrm{O}$ armazenamento do produto é realizado em freezers ou geladeiras, na própria residência. Para fabricação de catados há disponibilidade de matéria-prima durante todo ano, considerando a diversidade de espécies utilizadas na elaboração do produto.

Em geral, a organização da atividade produtiva na família ocorre por meio da distribuiçáo das tarefas próximas à residência, atribuição das mulheres por serem compatíveis aos demais afazeres domésticos e aos cuidados com os filhos. Àquelas que demandam mais tempo fora de casa é de responsabilidade dos homens.

Conforme o recurso há mais ou menos dispêndio de tempo no feitio do catado. Entretanto, segundo as marisqueiras seu valor final não se relaciona às dificuldades em beneficiá-lo, mas sim à maior apreciação por parte do consumidor. A ostra, por exemplo, está dentre os catados mais trabalhosos e de menor valor. Já o siri é um dos catados mais valiosos, mas igualmente, demanda muito esforço em seu beneficiamento ${ }^{3}$.

\footnotetext{
3 - Em Diogo et al. (2008) há matrizes de avaliação do trabalho (quantidade de trabalho empreendido para o total de produto adquirido) das marisqueiras associando cada recurso também ao preço de venda.
} 


\section{Legendas utilizadas nos esquemas elaborados para cadeia produtiva dos catados}

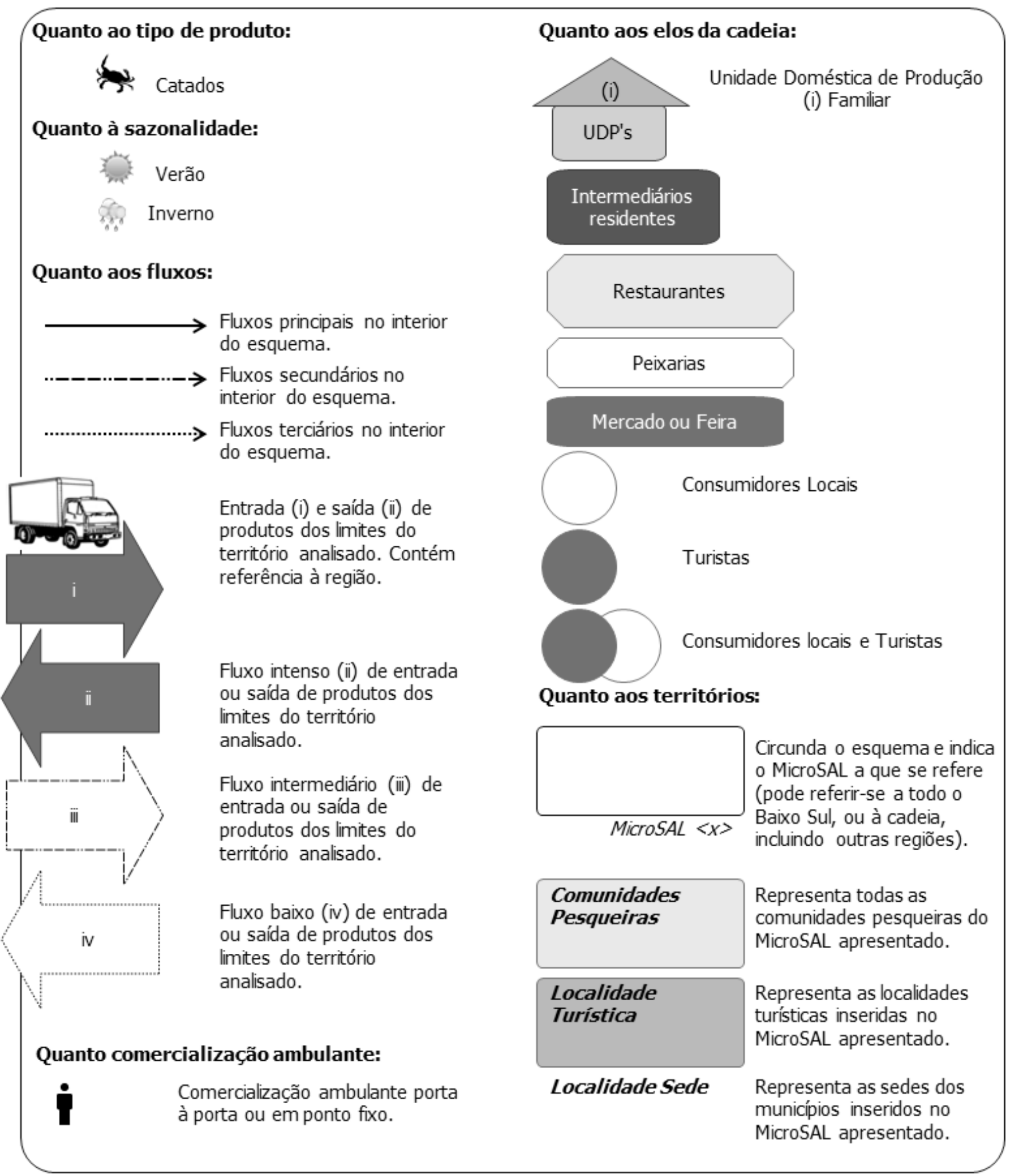

Figura 2. Estruturas da cadeia produtiva considerando sua inserção no território. Figure 2. Productive chain structures considering their insertion in the territory. 
A diversidade de recursos que compóem a categoria "catados" associado ao fato do produto ser processado não permitiu a análise sobre sua produção total, pois ao ser desembarcado o recurso pode ser destinado tanto à comercialização dos exemplares vivos (mariscos) como ao beneficiamento, de forma que as estatísticas realizadas com informaçóes no momento do desembarque dizem respeito aos dois produtos agrupados. Em adição, em virtude de a mariscagem ser uma atividade difusa, tais recursos comumente estáo subestimados nas estatísticas oficiais, o que dificulta ainda mais qualquer análise quantitativa.

Contudo, os catados são produtos gerados em todas as comunidades e bairros pesqueiros do litoral dos municípios estudados. Sua importância aumenta àquelas comunidades localizadas na contracosta das ilhas, em comunidades próximas a manguezais e principalmente, àquelas que se encontram no interior dos estuários.

Em relação aos fluxos de produção, as cadeias produtivas estáo circunscritas no interior do microssistema, sendo os canais de comercialização diversificados (Figuras 3, 4 e 5). As unidades domésticas de produção familiar (UDP's) abastecem tanto intermediários-residentes, peixarias e restaurantes, quanto aos intermediários-visitantes, feirantes e comércio ambulante, cobrindo assim todas as formas de abastecimento de frutos do mar observadas no Baixo Sul. Em menor frequência, verifica-se que alguns intermediáriosresidentes do microSAL norte e centro comercializam os produtos em Salvador, enviando-os por encomenda ou viajando de ônibus à capital nos fins de semana para vendêlos nas feiras.

Para as comunidades pesqueiras e bairros situados às margens da rodovia BA 001 aumenta a importância da comercialização junto a turistas de passagem, principalmente por intermediários-residentes e peixarias.

Especificamente no microSAL sul, os catados são destinados pelas UDP's à Itacaré, município de expressividade turística. Em Camamu, uma das peixarias comercializa os catados em Vitória - ES. Na sede do município de Camamu, a comercialização é realizada por ambulantes ou peixarias, não ocorrendo na feira. $\mathrm{O}$ produto é importante no abastecimento da população do próprio Baixo Sul em geral, tanto no litoral como no interior do território.

Apesar de existir oferta de catado ao longo de todo o ano, há oscilações significativas nos preços pagos às UDP's que podem chegar ao dobro ou ao triplo no verão ${ }^{4}$. Os entrevistados observam que neste período a procura pelo produto nas comunidades é maior, incluindo o microSAL centro que náo possui turismo expressivo.

Enquanto a maior parte das peixarias mencionou adquirir quantidades mensais equitativas ao longo do ano,

4 - Pescadores relataram que o quilo do siri, por exemplo, sobe de $\mathrm{R} \$ 6,00$ para $\mathrm{R} \$ 12,00$. Em Diogo et al. (2008) são descritos valores de comercialização de catado por $\mathrm{R} \$ 5,00$ chegando a $\mathrm{R} \$ 15,00$ no verão.

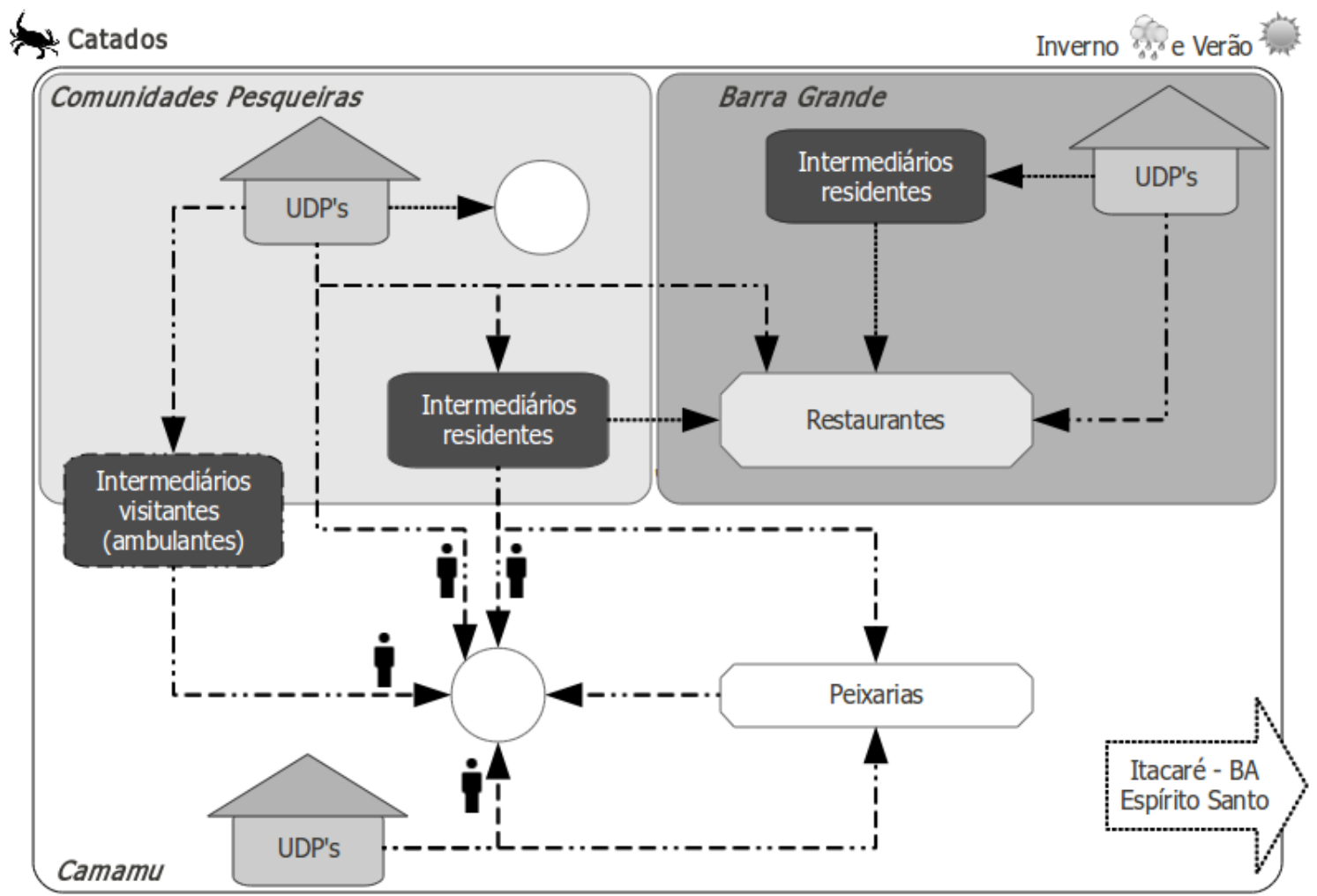

MicToSAL SUI

Figura 3. Fluxo de catados no microSAL sul. No verão, aumenta a demanda no sistema, mas não há alteração nos fluxos.

Figure 3. Shellfish flux in the microSAL sul. In summer, the demand in the system is higher, but does not change the fluxes. 


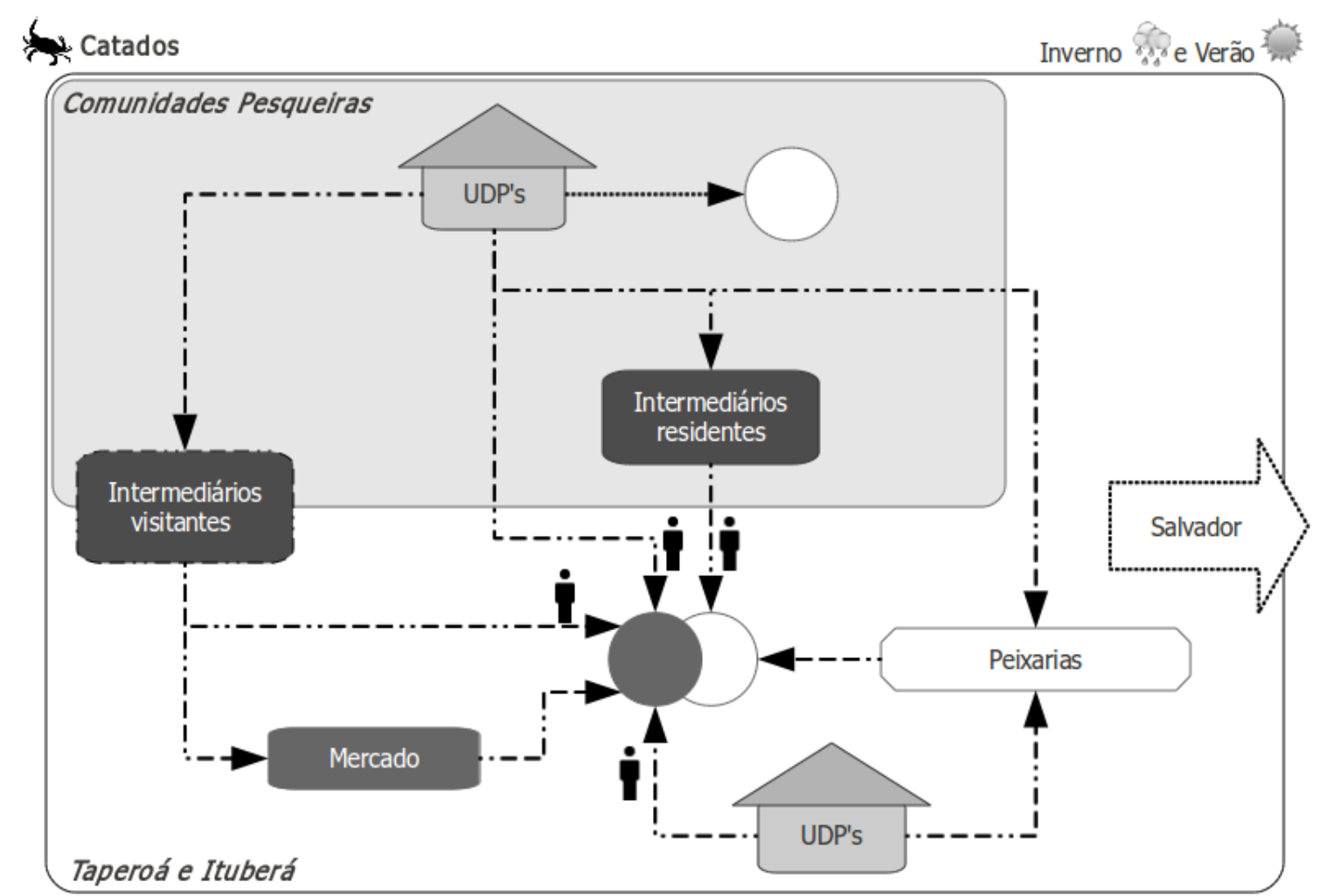

MictoSAL Centro

Figura 4. Fluxo de catados no MicroSAL centro.

Figure 4. Shellfish flux on the MicroSAL centro.

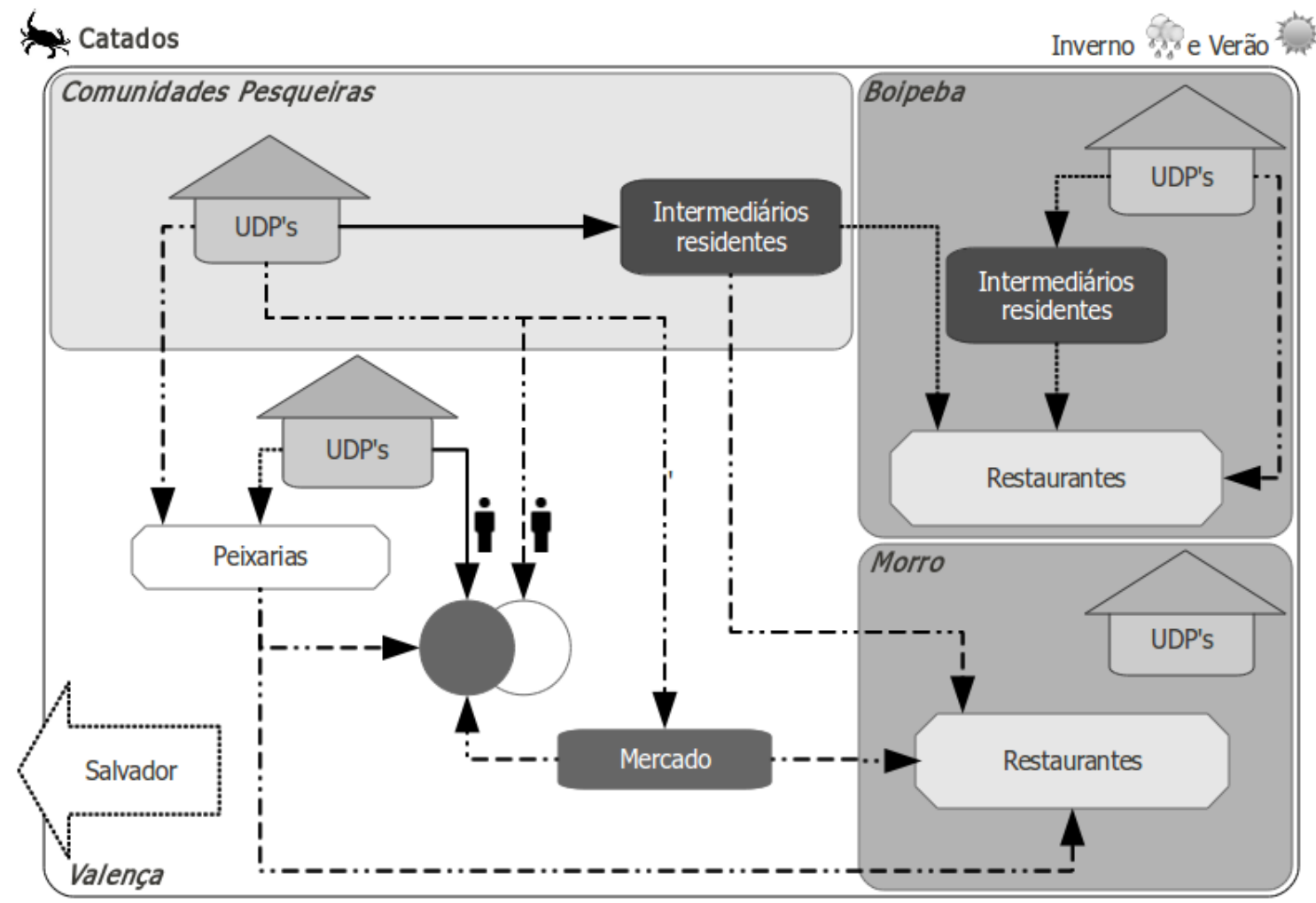

MictoSAL Norte

Figura 5. Fluxo de catados no MicroSAL norte.

Figure 5. Shellfish flux on the MicroSAL norte. 
o que caracteriza uma demanda constante, os restaurantes de fato observaram que seu consumo aumenta nos meses de verão, mas em poucas quantidades. Em geral apresenta oferta regular, ou seja, não há safra e entressafra expressivas.

A aquisição direta entre restaurantes e UDP's ocorre ao longo de todo ano, tanto em Barra Grande como em Boipeba. Já em Morro de São Paulo, os catados são oriundos de comunidades pesqueiras adjacentes e são adquiridos, principalmente, de intermediários-residentes. O abastecimento de catados pelas UDP's da própria localidade de Morro de São Paulo não foi citado por nenhum restaurante. Tampouco foram identificadas marisqueiras nesta localidade, dado a pujança do turismo local, que tem deslocado pescadores e marisqueiras para a atividade turística.

Verifica-se a permanência dos diversos fluxos entre elos da cadeia produtiva no inverno e no veráo, ainda que no segundo período eles ocorram em maior intensidade.

Dado os diversos canais de abastecimento e formas de comercialização dos catados não foi possível compreender os motivos que geram acréscimo táo significativo no preço dos produtos durante o verão, pois não parece ser plausível a justificativa entre oferta e demanda uma vez que os restaurantes - considerados aqueles que oferecem melhores preços na região - se abastecem diretamente nas localidades turísticas e/ou naquelas adjacentes a elas e com quem se relacionam ao longo de todo ano. Em paralelo, os demais canais de intermediação também se mantêm permanentes, sendo igualmente abastecidos pelas unidades domésticas ao longo do veráo.

Acredita-se, assim, que os preços praticados no verão são resultado da crença, por parte das unidades produtivas, sobre a maior demanda devido ao turismo. Como consequência, as unidades produtivas estabelecem uma relação de menor dependência com o comprador neste período, atribuindo aos produtos o valor que considera justo dentre aquele aceito pelo comerciante.

Contudo, apesar da produçáo de catados, em conjunto aos demais frutos do mar que demandam cuidados relacionados à conservação e à apresentação dos produtos, conferirem às mulheres maiores atribuiçôes no âmbito das unidades domésticas, este papel não é reconhecido, nem pela sociedade, nem no seio familiar. Em geral, as atividades realizadas pelos homens, principalmente aquelas relacionadas à pesca embarcada são atribuídas maior valor, ainda que as mulheres creditem às suas atividades uma contribuição de cinquenta por cento na renda familiar (Diogo et al., 2008). $\mathrm{Na}$ análise de Paulilo (1987) a autora chama atenção para a desvalorização do trabalho feminino, e infantil; que independente de sua natureza; é considerado leve e recebe remuneração inferior a do trabalho realizado por homens.

$\mathrm{O}$ maior valor à pesca embarcada foi expresso em várias entrevistas junto aos restaurantes e peixarias, que conferem a essas pescarias uma maior produtividade e consequentemente, maior importância na cadeia produtiva, relegando em segundo plano a pesca realizada nos estuários e manguezais e, especialmente, o papel das mulheres em tais atividades.

Ademais, catados são considerados os produtos com maior perecibilidade e críticas são feitas ao manuseio no processo de beneficiamento realizado pelas mulheres, ainda que nenhum estabelecimento assuma esse trabalho que é considerado demasiado exaustivo. Tal crítica se insere no rol de preconceitos associados às marisqueiras, uma vez que a sistemática de descongelar e congelar novamente o produto com vistas a um segundo beneficiamento pelos demais elos na cadeia é uma prática igualmente inadequada em termos sanitários. A análise sobre as condiçóes sanitárias dos catados em comparação aos demais frutos do mar, denota que pescados são manipulados e armazenados em condiçóes igualmente inadequadas e, por inúmeras vezes, congelados e descongelados ao longo da cadeia e até por um mesmo ator. Entretanto, não foram alvos de tais críticas. $\mathrm{O}$ receio em consumir e/ou comercializar um catado em baixas condiçóes sanitárias foi apresentado com a principal preocupaçáo em relação ao menor consumo deste produto, comparando-o aos demais produzidos pelas UDP's, por turistas que frequentam a regiāo.

\subsection{Ambiente Institucional}

$\mathrm{Na}$ análise de cadeias produtivas é possível identificar instituições que orientam o comportamento e as transações entre os atores sociais, estando mais ou menos presentes conforme a cadeia em questão ${ }^{5}$.

Para os catados, os aspectos relacionados à manipulação dos produtos e de sua conservação, consistem em uma instituição relevante. Apesar da existência de regulação específica para os produtos de origem animal, cuja expressão mais comum refere-se à obtenção de $\operatorname{SIF}^{6}$, não há por parte do poder público, na prática, qualquer rito que oriente a manipulação e o armazenamento dos catados ao longo desta cadeia. Contudo, apesar da ausência de regulação, o comportamento dos atores situados nos diversos elos é orientado por uma concepçáo de qualidade em que a manipulação doméstica é considerada uma prática inadequada. Como saída, duas práticas são frequentes ao longo da cadeia produtiva: i) descongelar o produto e beneficiá-lo novamente com vistas à remoção de partes da casca que ainda estão presentes e congelá-lo; ou ii) adquirir o produto de comunidades ou famílias reconhecidas pelo zelo no preparo e consequentemente, asseguram um produto de "qualidade superior". Ou seja, manter uma relação de confiança junto às unidades produtivas.

Náo obstante, o poder público se apresenta como um entrave à melhoria das práticas sanitárias para os diversos frutos do mar o que dificulta a formalização das cadeias produtivas. Tal situação é consequência da inadequação das exigências legais à realidade da pesca artesanal cujas estruturas de processamento e de conservação exigidas no âmbito do Serviço de Inspeção de Produtos Agropecuários vinculado ao Ministério da Agricultura - SIPAG demandam altos custos de manutenção, grandes quantidades de matéria-prima e um conjunto de exigências administrativas burocráticas,

5 - Neste artigo, a análise institucional se restringiu àquelas instituições que aparecem como expressivas na cadeia produtiva dos catados e náo da totalidade dos aspectos institucionais investigados. Ou seja, é possível que uma instituição exista, mas se ela não é evidenciada pelos atores, ela não é explicativa de comportamentos e transaçóes ao longo da cadeia produtiva.

6 - Serviço de Inspeção Federal. 
que de forma análoga à agricultura familiar (Wilkinson, 2008), mantêm as famílias de pescadores artesanais alijadas da agroindústria. Além da questão sanitária, duas outras instituiçóes se revelam importantes na cadeia produtiva dos catados: i) saúde laboral; e ii) degradação ambiental.

A (falta de) saúde das marisqueiras resultante das práticas do trabalho cotidiano foi destacada como uma das maiores preocupações deste grupo, seja nas etapas relacionadas à extração do recurso, seja naquelas associadas ao beneficiamento. As enfermidades de marisqueiras, tais como: hipertensẫo, diabetes, infecçôes ginecológicas (decorrentes da permanência prolongada no mangue), problemas de coluna (hérnias e contusôes), varizes, artroses, reumatismos, osteoporoses, LER - lesōes causadas por esforço repetitivo, problemas oftálmicos (decorrentes da frequente exposição ao sol), problemas respiratórios, micoses, câncer de pele e descolamento das unhas (decorrente do beneficiamento do marisco) foram reportadas por todas as comunidades na regiáo do Baixo Sul, analisadas por meio de dados secundários, e reiteradas nos debates realizados no âmbito do Projeto CIPAR.

Estudos realizados na área de saúde ocupacional denotam que esta realidade é comum à pesca artesanal no país, apesar dos escassos trabalhos sobre a temática. Em relação às marisqueiras, Pena et al. (2008) realizaram um estudo sobre suas condições de trabalho na Ilha de Maré, na Bahia, especificamente sobre LER. Segundo os pesquisadores, observou-se a realização média de 10.200 movimentos repetidos por hora de trabalho ${ }^{7}$. Concluiu-se que as marisqueiras devem ser incluídas dentre os grupos sociais de risco que realizam esforços excessivos e repetitivos.

Os autores ressaltam que "diferentemente das categorias assalariadas de serviços e indústrias, as cadências infernais observadas na extração de mariscos ocorre não por posiçôes de gerências, mas por exigências das condiçôes de sobrevivência com vistas a se evitar a miséria e a fome". Assim, a alternativa para a melhoria das condições de trabalho perpassa pela valorização do trabalho e de seu produto. Associado a isto, tem-se a necessidade de buscar alternativas técnicas e ergonômicas de forma a diminuir a carga excessiva de trabalho, prever pausas, instrumentos de trabalho adequados, acesso aos serviços preventivo, curativo e de reabilitação. Neste sentido, os autores alertam que a necessidade de intervenção por parte do Estado articulando o Sistema Único de Saúde - SUS, a Previdência Social e o MPA.

Este é o posicionamento que prevalece entre as marisqueiras do Baixo Sul. Para elas, a melhoria da cadeia produtiva dos frutos do mar e da organizaçáo social perpassa pela promoção da saúde do trabalhador incluindo a existência de mecanismos de seguridade social adequados à realidade do setor, o que demanda uma ação articulada entre os três entes.

No que tange ao processo de degradaçáo ambiental outra instituição relevante na cadeia produtiva dos catados - o mesmo não se restringe à diminuição da disponibilidade de matéria-prima à pesca extrativa devido à intensidade de

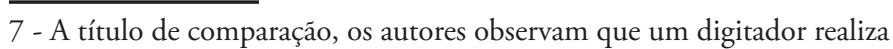
8.000 toques por hora, em média. pesca e/ou ao uso de petrechos inadequados. Consubstancia o processo de ocupação desordenada, agravados face à ausência e/ou ineficácia de instrumentos de ordenamento, regulação e fiscalizaçáo por parte do Estado que venham a assegurar a gestáo ambiental pública ${ }^{8}$.

Apesar dos relatos diferenciarem em relação a sua localização, no interior da sede ou em comunidades afastadas da mesma, denota a presença de fenômenos e fatores que estáo correlacionados, sendo inerentes a toda a região litorânea do Baixo Sul. A intensidade desses fenômenos, entretanto, é percebida de forma diferenciada em cada microSAL, a exemplo dos efeitos do turismo, observados pela maior parte das comunidades diagnosticadas no microSAL norte e pouco evidenciada por aquelas do sul.

Dentre os diversos fenômenos de ocupação do território e processos de degradação ambiental, destacamos para os catados à expansão urbana sobre áreas de manguezais por meio do seu aterramento e destinação de resíduos sólidos e de efluentes sem tratamento. Tal fato, expresso principalmente pelas marisqueiras de Valença e Taperoá, é associado à migração de pessoas oriundas da zona rural que buscam melhores oportunidades na cidade frente à crise vivida nas áreas rurais do Baixo Sul, bem como, o aumento de pessoas na região a procura de trabalho em virtude do advento do turismo na região. Esta última situação é mais expressiva em Valença, frente ao seu papel no apoio às atividades turísticas de Morro de São Paulo.

$\mathrm{O}$ processo de degradaçấo dos mangues nas sedes dos municípios gera diminuição da disponibilidade de recursos próximos à moradia, contaminação dos produtos e aumento de doenças às trabalhadoras que frequentam esses ambientes. Cada vez mais, marisqueiras residentes nas áreas urbanas necessitam maior disponibilidade de tempo e de meios de transporte para recorrer a áreas mais distantes o que implica em mais gastos na atividade e por vezes, a submissão a um sistema de partilha injusto de produção. No caso das mulheres, os afazeres domésticos e demais cuidados com a família lhes impóem mais restrições de tempo e de busca por outros pesqueiros.

Nas localidades situadas distantes da sede, o processo de degradação nos manguezais, além de relacionados à expansão do turismo, petróleo e maricultura é oriundo da extração de madeira de mangue, degradação do ambiente de Mata Atlântica, da ocupação de hotéis, com destaque para os do tipo resorts. Esses últimos são uma fonte específica de preocupaçấo, dado que diversas das fazendas na regiấo estão sendo vendidas a grupos estrangeiros para esta finalidade. Marisqueiras temem pela perda do acesso à praia e aos pesqueiros; perda de áreas de roça e de acesso aos recursos vegetais extraídos, tais como a piaçava. Destaca-se

8 - A crítica ao Estado é exposta aqui assumindo seu papel central na gestão ambiental pública. Cabe ao Estado, enquanto Poder Público, criar as condiçóes para que o espaço da gestão ambiental seja um espaço público, evitando que as decisões tomadas privilegiem os atores sociais com mais visibilidade e influência na sociedade e deixem de fora outros atores, geralmente, os mais impactados negativamente. Portanto, é o Poder Público que media os interesses e conflitos entre atores sociais, definindo os modos de destinaçáo dos recursos ambientais na sociedade (Quintas, 2009). 
que, em diversas comunidades rurais a atividade pesqueira é alternada à agricultura e/ou ao extrativismo vegetal, o que na definição de Diegues (1983) configura o pescadoragricultor. A perda de áreas de roça resulta em diminuição da diversidade de trabalho, maior tempo destinado à mariscagem e consequentemente, maior pressão sobre os estoques. Consequentemente, o maior esforço de pesca não é resultante de um comportamento economicista, que visa maior lucro, mais sim do conjunto de atividades econômicas no território que expulsam essas comunidades e intervém em seu meio de vida.

Como fator agravante à degradaçáo ambiental, tem-se um quadro de regulamentação e fiscalização ambiental pouco efetivo na região cujos efeitos resultam em maiores privações e prejuízos àqueles que não detêm o poder econômico e político. Principalmente em relação à fiscalização, pesa aos pescadores o teor da lei ao mesmo tempo em que o sistema falha em fiscalizar crimes ambientais de responsabilidade dos demais entes.

Assim, a questão ambiental perpassa pela estruturação do Estado e da construção de processos que envolva os moradores na gestão ambiental de forma a assegurar a manutenção deste patrimônio enquanto bem coletivo e necessário à reprodução social das marisqueiras.

\section{CONCLUSÓES}

A cadeia produtiva dos catados é caracterizada pela participação das mulheres nas etapas de extração e beneficiamento. Seus produtos abastecem os diferentes mercados do Baixo Sul: restaurantes em localidades turísticas, moradores do litoral e moradores do interior do território. A intermediação envolve todos os tipos de atores existentes: intermediários (residentes e visitantes), peixarias, feirantes e ambulantes. Fora do Baixo Sul, ainda que em menor escala, os catados são destinados às feiras de Salvador e ao estado do Espírito Santo.

A constância de matéria-prima associada à diversidade de estratégias de comercialização junto às unidades domésticas e à possibilidade de conservação do produto no interior da residência resulta em fluxos contínuos de catado ao longo do ano.

Estas características, associadas a pouca necessidade de insumos, deflagra certa autonomia das unidades produtivas em relação à comercialização, gerando inclusive ganhos de renda no período de veraneio.

Entretanto, o aumento da degradação dos manguezais em áreas próximas às residências das marisqueiras resulta em diminuiçáo na disponibilidade de matéria-prima, o que demanda a procura por novos pesqueiros mais distantes $\mathrm{e}$, consequentemente, a necessidade de canoas para o transporte. Estas, quando alugadas, as remetem a um sistema de partilha que envolve um novo ator: o proprietário da embarcação, diminuindo a fração da produção destinada à unidade familiar, a despeito do maior dispêndio de tempo para realização da atividade produtiva.

Considerando as demais atribuiçóes das mulheres, tanto na elaboração de outros produtos como frente aos afazeres domésticos, tem-se na degradação dos manguezais um processo que concatena sobrecarga de trabalho com perda de produção e renda.
Não obstante, a degradação dos manguezais resulta, também, em perda da qualidade do produto e de saúde destas trabalhadoras.

Outro fator relevante nesta cadeia produtiva é a saúde laboral das marisqueiras que culmina na ausência de mecanismos de seguridade social. Ou seja, para além das dificuldades de realização do trabalho, não há nenhum sistema de proteção por parte do Estado brasileiro, que reconheça as enfermidades como fruto das condiçóes de trabalho, sejam elas preventivas, curativas ou de reabilitação.

Por último, aspectos sanitários na manipulação do produto remetem para um menor consumo e algumas práticas pelos demais atores presentes na cadeia: i) o re-beneficiamento; ii) a aquisição de produtos de comunidade ou unidade produtiva reconhecidas por seu produto, ou seja, o estabelecimento de um sistema de confiança.

Este conjunto de fatores, analisados de forma articulada por meio do aporte teórico-analítico adotado, remetem à complexidade e à fragilidade desta cadeia produtiva, em especial em relação à degradaçáo ambiental, impondo as mulheres maior carga de trabalho, piores condiçôes de saúde e o risco de perda do fornecimento de uma proteína de importância local, bem como, de um patrimônio cultural.

Ademais, oferece um quadro analítico importante ao processo de gestão costeira, corroborando a necessidade em compreender a atividade pesqueira de forma sistêmica e territorializada, atentando-se aos processos de ocupação da zona costeira e marinha para além do esforço de pesca.

\section{AGRADECIMENTOS}

Agradecemos a todos os pescadores e marisqueiras participantes do Projeto CIPAR Baixo Sul, ao MPA pelo financiamento da pesquisa; à CGPEG/IBAMA pelo acesso ao acervo de dados; à Coordenação e Aperfeiçoamento de Pessoal de Nível Superior - CAPES pela concessão da bolsa de doutorado. A Cristiano Dapper, Fabiana Cava, Luciara Figueira e Márcio Rangel pelo auxílio na coleta de dados e a Yuri Walter pela organização dos esquemas sobre a cadeia produtiva.

\section{BIBLIOGRAFIA}

Batalha, M.O; Silva, A.L. da (2007) - Gerenciamento de Sistemas Agroindustriais: Definiçóes, Especificidades e Correntes Metodológicas. In: Batalha, M.O. (org.), Gestão Agroindustrial. Vol. 1, pp. 1-60, $3^{\text {a }}$ Edição, Editora Atlas, São Paulo, SP, Brasil. ISBN: 8522445702.

Boltansky, L.; Thévenot, L. (1991) - De la justification: les économies de la grandeur. 483p., Éditions Gallimard, Paris, France. ISBN: 2070722546.

CAR (1997) - Programa de Desenvolvimento Regional Sustentável - PDRS Sul da Bahia. 217p., Companhia de Desenvolvimento e Ação Regional - CAR (BA), Salvador, BA, Brasil. Disponível em: http://www.car.ba.gov.br/ uploads/publicacoes_34.pdf.

Coraggio, J.L. (2000) - Da economia dos setores populares à economia do trabalho. Questóes debatidas. In: Kraychete, G.; Lara, F.; Costa, B. (orgs.), Economia dos Setores Populares: Entre a Realidade a Utopia.pp. 91-141, Editora Vozes, Petrópolis, RJ, Brasil. ISBN: 8532624804. 
Diegues, A.C.S. (1983) - Pescadores, Camponeses $e$ Trabalhadores do Mar. 287p., Editora Ática, São Paulo, SP, Brasil. Disponível em: http://nupaub.fflch.usp.br/ sites/nupaub.fflch.usp.br/files/color/prof\%204.pdf.

Diogo, H.L.; Figueira, L.D.; Gomes, M.A.O. (2008) Relatório Final: Plano de Compensaçâo da Atividade Pesqueira no Bloco BMCal-4. Subsídios para Gestão Compartilhada das Pescarias Artesanais no Baixo Sul. 224p., El Paso Óleo e Gás, Rio de Janeiro, RJ, Brasil. Náo Publicado.

Fischer, F. (2007) - O que é o Baixo Sul? In: Fischer, F. (org.), Baixo Sul da Bahia: Uma proposta de desenvolvimento territorial. pp. 31-94, Editorial CIAGS, Salvador, BA, Brasil. ISBN: 978-85-60660-00-1. Disponível em: http://www.veracel.com.br/LinkClick.aspx?fileticket=X HNTAxLguUo\%3D\&tabid=115\& mid=468.

Fundação Prozee; Seap/PR; Ibama (2006) - Relatório Técnico Final: Monitoramento da Atividade Pesqueira no Brasil. 328p., Brasília, DF, Brasil. Não publicado. Disponível em: http://www4.icmbio.gov.br/cepene/download.php?id_ download $=319$.

Gereffi, G. (1999) - International Trade and Industrial Upgrading in the Apparel Commodity Chain. Journal of International Economics, 48(1):37-70. DOI: 10.1016/ S0022-1996(98)00075-0.

Gereffi, G.; Humphrey, J; Sturgeons, T. (2005) - The governance of global value chain: an analytical framework. Review of International Political Economy, 12(1):78-104. DOI: 10.1080/09692290500049805.

Granovetter, M. (1973) - The Strength of Weak Ties, American Journal of Sociology. (ISSN: 0002-9602) 78(6):1360-1380, Chicago, IL, U.S.A. Disponível em: http://www.jstor.org/ discover/10.2307/2776392? uid=3737664\&uid=2\&uid= 4\&sid=21101272479137.

Granovetter, M. (1974) - Getting a Job: A Study of Contact and Careers. 251p., $1^{\mathrm{a}}$ edição, 251p., Havard Univerity Press. Cambridge, MA, U.S.A., ISBN: 0674354168.

Granovetter, M. (1985) - Economic action and social structure: the problem of embeddedness. American Journal of Sociology, 91(3):481-510. Disponível em: http://www.jstor.org/discover/10.2307/2780199?uid=3 737664 \&uid $=2 \&$ uid $=4 \&$ sid $=21101272479137$.

Granovetter, M. (1992) - Economic Institutions as Social Constructions: A Framework for Analysis. Acta Sociologia, 35(1):3-11. DOI: 10.1177/000169939203500101.

Haguette, T.M.F. (1999) - Metodologias Qualitativas na Sociologia. 224p., Editora Vozes, Petrópolis, RJ, Brasil. ISBN: $853260854 x$.

Lins, H.N. (2006) - Sistemas agroalimentares localizados: possível "chave de leitura" sobre a maricultura em Santa Catarina. Revista de Economia Sociologia Rural,44(2):313330. DOI: $10.1590 /$ S0103-20032006000200008.

MDA (2010) - Plano de Desenvolvimento Territorial Sustentável do Território Baixo Sul da Bahia. 136p., Ministério do Desenvolvimento Agrário, Brasília, DF, Brasil. Disponível em: http://sit.mda.gov.br/download/ ptdrs/ptdrs_qua_territorio021.pdf .

Ministério da Pesca e Aquicultura (2010) - Registro Geral da Pesca - RGP.

Muchnik, J. (2006) - Sistemas agroalimentarios localizados: evolución del concepto y diversidad de situaciones. III
Congreso Internacional de la RED SIAL "Alimentación y Territórios”, 20p., Baeza (Jaén), Espanha. Disponível em: http://syal.agropolis.fr/ALTER06/pdf/actes/c14.pdf.

Paulilo, M.I.S. (1987) - O Peso do Trabalho Leve. Revista Ciência Hoje, 28:64-70,. Departamento de Ciências Sociais, UFSC, Florianópolis, SC, Brasil. Disponível em: ht tp://nafa.paginas.ufsc.br/files/2010/09/ OPesodoTrabalhoLeve.pdf.

Pena, P.G.L; Freiras, M.C.S.; Cardin, A. (2011) - Trabalho artesanal, cadências infernais e lesóes por esforços repetitivos: estudo de caso em uma comunidade de mariscadeiras na Ilha de Maré, Bahia. Ciência e Saúde Coletiva (ISSN 1413-8123), 16(8):3383-3392, Rio de Janeiro, RJ, Brasil. Disponível em: http://www.scielosp. org/pdf/csc/v16n8/a05v16n8.pdf.

Phyne, J.; Mansilla, J. (2003) - Forging Linkages in the Commodity Chain: The Case of Chilean Salmon Farming Industry, 1987-2001. Sociologia Ruralis, 43(2):108-127. DOI: $10.1111 / 1467-9523.00234$.

Ponte, S. (2008) - Greener than Thou: The Political Economy of Fish Ecolabeling and Its Local Manifestations in South Africa. World Development, 36(1):159-175. DOI: 10.1016/j.worlddev.2007.02.014.

Quintas, J.S. (2009) - Educação no processo de gestão ambiental pública: a construção do ato pedagógico. In: Loureiro, C.F.B.; Layrargues, P.P.; Casto, R.S. (orgs.), Repensar a Educação Ambiental: Um olhar crítico, pp. 33-80, Editora Cortez, São Paulo, SP, Brasil. ISBN: 8524915021.

Santos, M.A.S. dos (2005) - A cadeia produtiva da pesca artesanal no Estado do Pará: Estudo de caso no nordeste paraense. Amazônia: Ciência \& Desenvolvimento, (ISSN: 1809-4058) 1(1):61-81, Banco de Desenvolvimento da Amazônia (BASA), Belém, PA, Brasil. Disponível em: h t t p / / www.basa.com.br/bancoamazonia 2 / Revista/061a082.pdf.

Walter, T. (2010) - Novos Usos e Novos Mercados: Qual sua influência na dinâmica da cadeia produtiva dos frutos do mar oriundos da pesca artesanal? 372p., Tese de Doutorado, Universidade Federal Rural do Rio de Janeiro (UFRRJ), Seropédica, RJ, Brasil. Disponível em: http://r1.ufrrj. br/cpda/wp-content/uploads/2011/08/tese_tatiana_ walter_2010.pdf.

Walter, T.; Wilkinson, J. (2011) - Fortalecimento da Cadeia Produtiva da Pesca Artesanal no Baixo Sul Baiano. Agriculturas: Experiência em Agroecologia (ISSN: 1807491X), 8(3):26-33, Rio de Janeiro, RJ, Brasil. Disponível: http://aspta.org.br/wp-content/uploads/2011/11/ artigo-5.pdf

Walter, T; Silva, P.A.; Valença, M. (2012) - Limites e Possibilidades na Gestão Compartilhada da Pesca Artesanal Urbana. Uma Reflexão a partir do Contexto Pernambucano. 19p., Anais: VI Encontro Nacional da ANNPAS, Belém, PA, Brasil. Disponível em: http:// www.anppas.org.br/encontro6/anais/gt12.html.

Wilkinson, J. (2008) - Mercados, Redes e Valores. 213p, Editora UFRGS, Porto Alegre, RS, Brasil. ISBN: 853860032x.

Zylbersztajn, D. (2000) - Conceitos Gerais, Evolução e Apresentação do Sistema Agroindustrial. In: Zylberstajn, D; Neves, M.F. (org.), Economia e Gestão de Negócios Agroalimentares, pp. 1-21. Editora Pioneira, São Paulo, SP, Brasil. ISBN: 8522102171. 


\section{APÊNDICE 1 - CATEGORIAS ELABORADAS PARA DIAGNÓSTICO DA CADEIA PRODUTIVA POR MEIO DE INFORMAÇÓES SECUNDÁRIAS.}

1. Informaçóes Gerais sobre a comunidade pesqueira:
a) Nome da comunidade;
b) Município;
c) MicroSAL;
d) Fontes de Informação;
e) Ano de referência

2. Caracterização da Unidade Doméstica de Produção UDP:

a) Tipos de UDP presente na comunidade: familiar e/ ou contratada;

b) Atribuição do homem na UDP;

c) Atribuição da mulher na UDP;

d) Outras atividades econômicas que compõem a renda familiar.

3. Caracterização dos meios de produção utilizados pelas UDP's nas comunidades:

a) Tamanho da frota;

b) Tipo de embarcação e de sistema de propulsão;

c) Regimes de propriedade da embarcação observados;

d) Tipos de petrecho de pesca;

e) Regimes de propriedade dos petrechos observados;

f) Ocupaçóes existentes relacionadas às embarcaçōes e petrechos;

g) Principais insumos utilizados na etapa de produção.

4. Produção Pesqueira:
a) Principais recursos capturados pelas UDP's;
b) Safras existentes;
c) Produção anual total estimada;
d) Áreas de pesca.

5. Armazenamento e beneficiamento dos frutos do mar:
a) Formas de acondicionamento dos frutos do mar à bordo;
b) Infraestrutura para desembarque;
c) Características do beneficiamento;
d) Regime de trabalho associado ao beneficiamento: familiar ou contratado;
e) Formas de conservação da produçáo pela UDP;
f) Estrutura de conservação presentes nas UDP's.

6. Características da $1^{\mathrm{a}}$ comercialização e dos intermediáriosresidentes:

a) Destino da produção: auto-consumo e/ou mercado;

b) Formas de comercialização realizadas pelas UDP's em cada comunidade: direta (rua, feira e restaurantes) e/ ou indireta (intermediário-residente, intermediáriovisitante, peixarias);

c) Número de atravessadores/peixarias residentes na comunidade (intermediário-residente):

d) Estruturas de conservação presentes na etapa de comercialização;

e) Estruturas de comercialização públicas ou coletivas e estado de funcionamento;

f) Destinação da produção pelo primeiro-intermediário: município/região; g) Características do fornecimento: restaurantes, peixarias, consumidores, mercado/feira, ambulante, etc.

7. Características político-institucionais:

a) Entidades representativas dos pescadores e marisqueiras;

b) Infraestrutura existente relacionada à organizaçáo;

c) Acesso aos direitos trabalhistas e de seguridade social (aposentadoria, seguro-defeso, bolsa-família);

d) Características do crédito;

e) Interferências externas: petróleo, turismo, aquicultura, etc;

f) Conflitos observados;

g) Projetos ou açóes educativas existentes com vistas à organizaçáo social dos pescadores e/ou estruturação da cadeia produtiva.

\section{APÊNDICE 2 - ROTEIROS DE ENTREVISTAS UTILIZADOS NO ÂMBITO DA PESQUISA}

a) Roteiro para entrevistas com restaurantes e bares:

1. Informaçóes da entrevista

\begin{tabular}{|l|l|l|}
\hline 1.1 & Localidade & Data: \\
\hline 1.2 & Entrevistadores: \\
\hline 1.3 & Nome do Restaurante/bar: \\
\hline 1.4 & Nome do entrevistado: \\
\hline 1.5 & Função no restaurante/bar: \\
\hline 1.6 & Contato: \\
\hline 1.7 & Tempo de existência na localidade (em anos): \\
\hline 1.8 & $\begin{array}{l}\text { Restaurante fica aberto o ano todo? ( ) Sim; ( ) Não, } \\
\text { qual o período (meses) }\end{array}$ \\
\hline
\end{tabular}

\section{Dados do proprietário}

\begin{tabular}{|l|l|l|}
\hline 2.1 & Nome: & \multicolumn{2}{|l|}{ 2.3 Idade: } \\
\hline 2.2 & Estado Civil: & 2.5 Sexo: \\
\hline 2.4 & Origem: & 2.7 No de dependentes: \\
\hline 2.6 & Escolaridade: & \multicolumn{2}{|l}{} \\
\hline 2.8 & Ocupação anterior: & \multicolumn{2}{|l|}{ Possui outra fonte de renda? ( ) não; ( ) sim. Qual? } \\
\hline 2.9 & \multicolumn{2}{|l}{}
\end{tabular}

\section{Importância do pescado para o restaurante/bar}

\begin{tabular}{|l|l|}
\hline 3.1 & $\begin{array}{l}\text { Dentre os pratos servidos, qual a importância dos frutos } \\
\text { do mar (em \%)? }\end{array}$ \\
\hline 3.2 & $\begin{array}{l}\text { Dentre os pratos confeccionados com frutos do mar, } \\
\text { qual o de maior saída? } \\
\text { nome do prato/matéria-prima/preço }\end{array}$ \\
\hline 3.3 & $\begin{array}{l}\text { E o de menor saída? } \\
\text { nome do prato/matéria-prima/preço }\end{array}$ \\
\hline 3.4 & $\begin{array}{l}\text { Quais são os principais tipos de pescado para o } \\
\text { restaurante/bar? }\end{array}$ \\
\hline
\end{tabular}




\section{Estratégias para aquisição e armazenagem dos} frutos do mar.

\begin{tabular}{|l|l|}
\hline 4.1 & $\begin{array}{l}\text { De quem e onde você costuma comprar os principais } \\
\text { frutos do mar? }\end{array}$ \\
\hline 4.2 & $\begin{array}{l}\text { Eles são comprados frescos ou congelados? Inteiros ou } \\
\text { em filé/catado? }\end{array}$ \\
\hline 4.3 & $\begin{array}{l}\text { Você estoca parte da produção? Porque? Qual sua } \\
\text { capacidade de estoque? }\end{array}$ \\
\hline 4.4 & $\begin{array}{l}\text { Conduzir a entrevista sobre a estratégia adotada pelo } \\
\text { restaurante de forma a compreender quais os principais } \\
\text { fatores são considerados (preço, regularidade de oferta, } \\
\text { qualidade sanitária, aspectos ambientais, fatores } \\
\text { sociais). Observar se há fidelidade ao vendedor e } \\
\text { porque e se é feito uso de espécies exóticas ou oriundas } \\
\text { da aquicultura. } \\
\text { Verificar se integra alguma rede/cadeia de restaurantes. }\end{array}$ \\
\hline
\end{tabular}

\section{Aplicar calendário}

\begin{tabular}{|l|l|}
\hline 6.1 & $\begin{array}{l}\text { Quais as principais dificuldades observadas pelo } \\
\text { senhor(a) para se trabalhar com pratos elaborados com } \\
\text { frutos do mar? }\end{array}$ \\
\hline 6.2 & $\begin{array}{l}\text { Como o senhor/senhora acha que a cadeia produtiva do } \\
\text { pescado no Baixo Sul poderia ser melhorada? }\end{array}$ \\
\hline
\end{tabular}

\section{Análise sobre a cadeia produtiva da pesca}

b) Roteiros para entrevistas com peixarias

1. Informaçóes da entrevista

\begin{tabular}{|l|l|l|}
\hline 1.1 & Localidade & Data: \\
\hline 1.2 & Entrevistadores: & \\
\hline 1.3 & Nome da Peixaria/comerciante: \\
\hline 1.4 & Nome do entrevistado: \\
\hline 1.5 & Contato: \\
\hline 1.6 & Tempo de existência na localidade (em anos): \\
\hline
\end{tabular}

\section{Dados do proprietário}

\begin{tabular}{|l|l|l|}
\hline 2.1 & Nome: & \multicolumn{2}{|l|}{} \\
\hline 2.2 & Estado Civil: & 2.3 Idade: \\
\hline 2.4 & Origem: & 2.5 Sexo: \\
\hline 2.6 & Ocupação anterior: \\
\hline 2.7 & \multicolumn{2}{|l|}{ Possui outra fonte de renda? ( ) não; ( ) sim. Qual? } \\
\hline
\end{tabular}

\section{Diversidade de frutos do mar na peixaria}

$3.1 \quad$ Verificar quais são os principais tipos de produtos (pescado de $1^{\mathrm{a}}, 2^{\mathrm{a}}, 3^{\mathrm{a}}$, mariscos vivos e catados) na peixaria.
4. Estratégias para aquisiçáo e armazenagem dos frutos do mar.

\begin{tabular}{|l|l|}
\hline 4.1 & $\begin{array}{l}\text { De quem e onde você costuma comprar os principais } \\
\text { frutos do mar? }\end{array}$ \\
\hline 4.2 & $\begin{array}{l}\text { Eles são comprados frescos ou congelados? Inteiros ou } \\
\text { em filé/catado? }\end{array}$ \\
\hline 4.3 & $\begin{array}{l}\text { Você estoca parte da produção? Porque? Qual sua } \\
\text { capacidade de estoque? }\end{array}$ \\
\hline 4.4 & $\begin{array}{l}\text { Conduzir a entrevista sobre a estratégia adotada pela } \\
\text { peixaria de forma a compreender quais os principais } \\
\text { fatores são considerados (preço, regularidade de oferta, } \\
\text { qualidade sanitária, aspectos ambientais, fatores } \\
\text { sociais). Observar como são estabelecidas as relaçóes } \\
\text { entre peixaria-pescador e entre peixaria-clientes e } \\
\text { se é feito uso de espécies exóticas ou oriundas da } \\
\text { aquicultura. }\end{array}$ \\
\hline
\end{tabular}

\section{Estratégias de venda adotada:}

5.1 Abordar para quem a peixaria vende pescado e se ele é destinado, também, a outros lugares fora do Baixo Sul. Pedir para o entrevistado dimensionar quanto de pescado vai para fora. Tentar o contato de alguns dos compradores que ficam fora do Baixo Sul.

\section{Aplicar calendário}

\section{Análise sobre a cadeia produtiva da pesca}

7.1 Como o senhor/senhora acha que a cadeia produtiva do pescado no Baixo Sul poderia ser melhorada?

\section{c) Modelo de calendário utilizado nas entrevistas}

Estabelecimento:

Localidade: Data:

\begin{tabular}{|l|l|l|l|l|l|l|l|l|l|l|l|l|}
\hline Meses & Jan & Fev & Mar & Abr & Mai & Jun & Jul & Ago & Set & Out & Nov & Dez \\
\hline Funcionários & & & & & & & & & & & & \\
\hline $\begin{array}{l}\text { Movimento } \\
\text { (para } \\
\text { restaurantes) }\end{array}$ & & & & & & & & & & & & \\
\hline
\end{tabular}

Aquisiçáo de matéria prima. Produtos e sub-categoria (quantidades/preço)

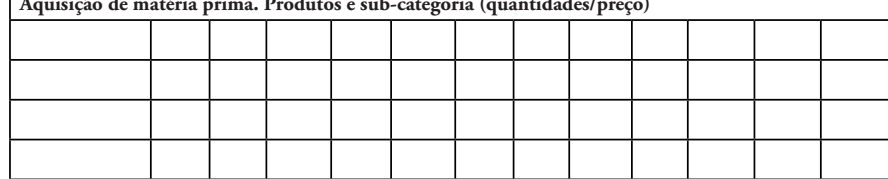

d) Roteiro para entrevistas junto a feirantes

Entrevistado: Banca $\mathrm{n}^{0}$ :

Data

Espécie $\rightarrow$ Origem, Forma beneficiamento, Forma de armazenamento, Preço compra, Preço venda, Para quem vende

Estrutura da feira $\rightarrow$ Insumos oferecidos, taxas pagas, Número de bancas, condiçóes da estrutura

Conversar sobre a estratégia de compra. 